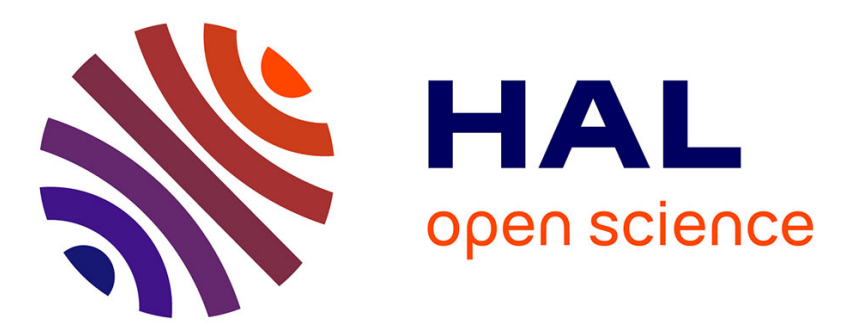

\title{
Layer growth mechanisms on metallic electrodes under anodic polarization in cryolite-alumina melt
}

\author{
Magaly Oudot, Laurent Cassayre, Pierre Chamelot, Mathieu Gibilaro, \\ Laurent Massot, Michèle Pijolat, Sylvie Bouvet
}

\section{To cite this version:}

Magaly Oudot, Laurent Cassayre, Pierre Chamelot, Mathieu Gibilaro, Laurent Massot, et al.. Layer growth mechanisms on metallic electrodes under anodic polarization in cryolite-alumina melt. Corrosion Science, 2014, vol. 79, pp. 159-168. 10.1016/j.corsci.2013.10.040 . hal-00948663

\section{HAL Id: hal-00948663 https://hal.science/hal-00948663}

Submitted on 18 Feb 2014

HAL is a multi-disciplinary open access archive for the deposit and dissemination of scientific research documents, whether they are published or not. The documents may come from teaching and research institutions in France or abroad, or from public or private research centers.
L'archive ouverte pluridisciplinaire HAL, est destinée au dépôt et à la diffusion de documents scientifiques de niveau recherche, publiés ou non, émanant des établissements d'enseignement et de recherche français ou étrangers, des laboratoires publics ou privés. 


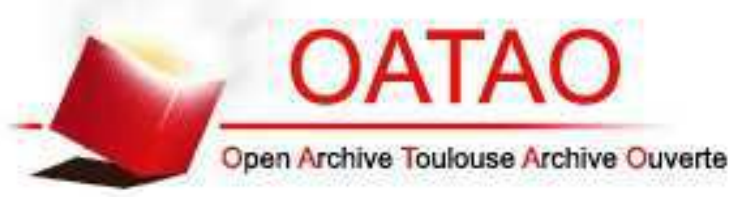

\section{Open Archive TOULOUSE Archive Ouverte (OATAO)}

OATAO is an open access repository that collects the work of Toulouse researchers and makes it freely available over the web where possible.

This is an author-deposited version published in : http://oatao.univ-toulouse.fr/ Eprints ID : 10973

To link to this article : doi:10.1016/j.corsci.2013.10.040

URL : http://dx.doi.org/10.1016/j.corsci.2013.10.040

To cite this version : Oudot, Magaly and Cassayre, Laurent and Chamelot, Pierre and Gibilaro, Mathieu and Massot, Laurent and Pijolat, Michèle and Bouvet, Sylvie Layer growth mechanisms on metallic electrodes under anodic polarization in cryolite-alumina melt. (2014) Corrosion Science, vol. 79 . pp. 159-168. ISSN 0010-938X

Any correspondance concerning this service should be sent to the repository administrator: staff-oatao@ listes-diff.inp-toulouse.fr 


\title{
Layer growth mechanisms on metallic electrodes under anodic polarization in cryolite-alumina melt
}

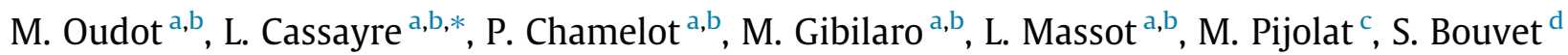 \\ a Université de Toulouse, INPT, UPS, Laboratoire de Génie Chimique, 118 Route de Narbonne, F-31062 Toulouse, France \\ ${ }^{\mathrm{b}}$ CNRS, Laboratoire de Génie Chimique, F-31062 Toulouse, France \\ ${ }^{\mathrm{c}}$ Ecole Nationale Supérieure des Mines SPIN-EMSE, CNRS, UMR 5307, LGF, 42023 Saint Étienne, France \\ ${ }^{\mathrm{d}}$ Rio Tinto Alcan, Aluval, 725 rue Aristide Berges, 38341 Voreppe, France
}

Keywords:

A. Iron

A. Nickel

A. Cobalt

A. Molten salts

B. Polarization

C. High-temperature corrosion

\begin{abstract}
A B S T R A C T
The anodic behavior of $\mathrm{Fe}, \mathrm{Ni}$, Co electrodes was investigated in a cryolite-alumina melt at $960{ }^{\circ} \mathrm{C}$, by electrochemical techniques, microstructural characterizations and thermodynamic calculations, to provide a fundamental understanding of layers formation at metal (M) electrode surface. At low overpotential, anodic dissolution of $\mathrm{M}$ occurs; when the $\mathrm{M}^{\mathrm{n}+}$ concentration at the surface reaches saturation, a $\mathrm{M}_{x} \mathrm{Al}_{3-x} \mathrm{O}_{4}$ spinel phase precipitates. Then, a dense $\mathrm{M}_{y} \mathrm{O}$ layer grows at the metal/spinel interface. As for Fe, polarization at higher overpotentials lead to the same layers of spinel and monoxide, but pores at the metal/ $\mathrm{Fe}_{y} \mathrm{O}$ interface cause loss of adhesion of the oxide film.
\end{abstract}

\section{Introduction}

The Hall-Héroult process for primary aluminum production consists of the electrolysis of alumina using consumable carbon anodes, which leads to the emission of carbon dioxide. For both environmental and economic reasons, the development of an inert or non-consumable oxygen-evolving anode is today one of the key challenges for the aluminum industry: $\mathrm{CO}_{2}$ emissions would be replaced by $\mathrm{O}_{2}$ emissions, and the use of inert anodes would avoid carbon consumption as well as many of the process inefficiencies and safety risks associated with anode replacement [1].

Among the possible materials (metals, ceramics and cermets) to be used as oxygen-evolving anodes, metals are regarded as good candidates due to their high electrical conductivity, mechanical strength and ease of fabrication. However, very few metals are inert under oxygen evolution and the objective is to obtain a material exhibiting good corrosion resistance in cryolite-alumina melts (CAM), with a protective oxide scale on the anode surface.

$\mathrm{Cu}, \mathrm{Ni}, \mathrm{Fe}$ and $\mathrm{Co}$ based-alloys appear to be the most promising materials for this application. Many studies have been performed on these alloys, both under polarization in CAM [1-8] and

\footnotetext{
* Corresponding author at: Université de Toulouse, INPT, UPS, Laboratoire de Génie Chimique, 118 Route de Narbonne, F-31062 Toulouse, France. Tel.: +33 561 5574 68; fax: +33561556139.

E-mail address: cassayre@chimie.ups-tlse.fr (L. Cassayre).
}

gas-phase oxidation [9-19]. The latter are not directly concerned with inert anode development, but provide interesting information on the corrosion mechanisms of these alloys and their ability to grow protective oxide layers.

Nevertheless, the understanding of the corrosion behavior of metals in CAM, and more specifically the mechanisms of the initial oxide layer formation under anodic polarization, has not been fully investigated. In most cases, research [2-4,6-8] focused on determining the corrosion rates of the anodes and/or the current efficiencies obtained for aluminum production. In the frame of more fundamental studies, a specific methodology was developed in a previous work [4] in the case of $\mathrm{Cu}-\mathrm{Ni}$ alloys.

As for iron, very few publications have been reported on its behavior as an anode. Antipov [2] performed cyclic voltammetry on Fe electrodes in a cryolite-alumina $\mathrm{Fe}_{2} \mathrm{O}_{3}$-containing mixture, and observed two cathodic/anodic peaks, at $0.9 / 1.5$ and $1.5 /$ $1.7 \mathrm{~V} / \operatorname{ref}\left(\mathrm{Al}^{3+} / \mathrm{Al}\right)$, corresponding to the $\mathrm{Fe}(\mathrm{II}) / \mathrm{Fe}$ and $\mathrm{Fe}(\mathrm{II}) / \mathrm{Fe}(\mathrm{III})$ transitions, respectively. Then, galvanostatic electrolyses at various polarization times and current densities were performed, followed by X-ray Diffraction (XRD) analyses of the samples. On the iron electrode polarized at $0.5 \mathrm{~A} / \mathrm{cm}^{2}$, the authors observed $\mathrm{Fe}_{3} \mathrm{O}_{4}$ at the anode/melt interface together with $\mathrm{FeF}_{3}$ and $(\mathrm{Fe}, \mathrm{Al})(\mathrm{AlFe})_{2} \mathrm{O}_{4}$. However, no micrography of the scale morphology was provided. Besides, no potentiostatic polarization was carried out, and the mechanisms of formation of these compounds were not detailed. 
The behavior of dissolved iron compounds in CAM was also examined: the solubility of $\mathrm{Fe}_{2} \mathrm{O}_{3}$ has been studied by Diep [20], while Jentoftsen investigated $\mathrm{Fe}(\mathrm{II})$ dissolution [21] and the solubility of $\mathrm{FeO}$ and $\mathrm{FeAl}_{2} \mathrm{O}_{4}$ [22]. These reports are of great interest, since the formation of protective oxide layers is highly dependent on the solubility of the oxidation products in the CAM.

The present work is mainly focused on the anodic behavior of iron during low potential and short time polarization. Rather than studying the behavior of this metal in aluminum production conditions (i.e. at high current densities), the aim was to provide a fundamental understanding of the initial oxide layers formation on the electrode surface, and consider whether or not the results could help to understand the degradation mechanisms of inert anodes. The role of potential, current density and polarization time was investigated. Then, metal surface and corrosion products were analyzed by scanning electron microscopy (SEM) coupled with energy dispersive spectrum (EDS), and electron probe microanalysis (EPMA). Based on thermodynamic calculations, the phase stability was determined in the various experimental conditions, in order to understand the corresponding oxidation mechanisms.

A similar study has been carried out on cobalt and nickel, in order to determine whether or not the oxidation mechanisms defined for iron could be extended to other metals, with properties close to those of iron.

\section{Materials and methods}

\subsection{Cell}

The cryolite melts were contained in a vitreous carbon crucible, which was placed in a graphite liner protecting the inside wall of a cylindrical vessel made of refractory steel. The cell was closed by a stainless steel lid cooled by circulating water. A schematic diagram of the experimental setup has already been presented elsewhere [23]. The gaseous atmosphere was U-grade (less than $5 \mathrm{ppm} \mathrm{O}_{2}$ ) inert argon dehydrated with a purification cartridge (Air Liquide).

\subsection{Chemicals and bath preparation}

The cryolite melt was composed of pure $\mathrm{Na}_{3} \mathrm{AlF}_{6}$ (Alfa Aesar, purity 99.9\%), with an 11 wt.\% excess of $\mathrm{AlF}_{3}$ (Alfa Aesar, purity 99.99\%) and 5 wt.\% of $\mathrm{CaF}_{2}$ (Merck, purity 99.95\%), leading to a cryolite ratio (CR) of 2.2. Alumina saturation was achieved by the addition of $9 \mathrm{wt} . \%$ of alumina.

Two hundred grams of the mixture were placed in the cell, and heated under vacuum to $120^{\circ} \mathrm{C}$ for $24 \mathrm{~h}$, then to $250^{\circ} \mathrm{C}$ for $48 \mathrm{~h}$, in order to dehydrate the salts. The cell was then filled with argon and heated up to $960{ }^{\circ} \mathrm{C}$.

\subsection{Electrodes}

Iron, nickel and coblat wires with a diameter of $1 \mathrm{~mm}$ (Goodfellow) were immersed $5-10 \mathrm{~mm}$ into the molten salt and used as working electrodes in a classical three-electrode setup. The actual immersed height was determined at the end of the run. The vitreous carbon crucible was used as counter electrode. Potentials were measured with respect to a platinum wire acting as a comparison electrode $\mathrm{Pt} / \mathrm{PtO}_{x} / \mathrm{O}^{2-}$. To ensure the stability of this electrode whose potential depends on the $\mathrm{O}^{2-}$ concentration in the CAM, the Pt wire was placed in a boron nitride container, filled with the salt mixture and drilled with a $0.2 \mathrm{~mm}$ diameter hole.

The equilibrium potential of the comparison electrode was regularly calibrated in regard of the oxygen evolution potential, determined by cyclic voltammetry on a gold working electrode. In this paper, all potentials are referred to the $\mathrm{AlF}_{3} / \mathrm{Al}$ potential, which corresponds to the standard potential of the system composed of liquid aluminum in equilibrium with liquid cryolite under $1 \mathrm{~atm}$. According to thermodynamics, under the experimental conditions, the $\mathrm{O}_{2}$ evolution potential versus the $\mathrm{AlF}_{3} / \mathrm{Al}$ system is equal to $2.18 \mathrm{~V}$. Thus, potentials measured relative to the Pt comparison electrode were recalculated versus the $\mathrm{AlF}_{3} / \mathrm{Al}$ system.

\subsection{Techniques and equipment}

Electrochemical measurements were carried out using an Autolab PGSAT30 potentiostat controlled by GPES software. Four electrochemical techniques were used. Linear sweep voltammetries were recorded at a sweep rate of $0.002 \mathrm{~V} / \mathrm{s}$. Potentiostatic polarization were performed at various potentials and polarization times. Open-circuit potentials were recorded after short anodic polarization. Electrochemical Impedance Spectroscopy (EIS) was performed at the Open Circuit Potential (OCP) at high frequencies (from $10^{3}$ to $10^{5} \mathrm{~Hz}$ ) on the electrode in order to determine the electrical resistance of the experimental set-up: the latter was measured to be around $0.7 \Omega$.

Scanning Electron Microscope (SEM) observations were performed on a Hitachi TM-1000. A Backscattered Electron (BSE) detector was used. Electron Microprobe Analyses (EPMA) and elemental mapping were performed on a CAMECA SX100.

Small gold markers $(0.4-0.5 \mu \mathrm{m})$ were deposited by Physical Vapor Deposition (PVD) using a Emitech K550X on some iron wires prior to electrochemical tests, in order to localize the initial interface. The current and time of deposition were $0.05 \mathrm{~A}$ and $120 \mathrm{~s}$, respectively.

The FactSage 6.3 software [24] was used to perform thermodynamic calculations.

\section{Experimental results}

\subsection{Electrochemical study}

\subsubsection{Linear voltammetry}

Linear sweep voltammetries were performed on iron, nickel and cobalt in the CAM. The potential was slowly increased (sweep rate $0.002 \mathrm{~V} / \mathrm{s}$ ) from the OCP to a potential higher than $2.18 \mathrm{~V} /\left(\mathrm{AlF}_{3} / \mathrm{Al}\right)$ $\left(\mathrm{O}_{2}\right.$ evolution). Typical voltammograms are presented in Fig. 1 for iron and gold and Fig. 2 for nickel and cobalt.

Although the results are not perfectly reproducible, in particular in terms of current density due to uncertainties in the measurement of the surface area, the trend between the different samples remains the same and the results are similar enough to be exploited.

The voltammogram on iron shows that oxidation reactions take place on the electrode, compared with gold electrode. Indeed, the current density starts increasing from $0.9 \mathrm{~V} /\left(\mathrm{AlF}_{3} / \mathrm{Al}\right)$, thus far below the $\mathrm{O}_{2}$ evolution potential. The absence of such currents on the gold electrode (cf. Fig. 1, dotted line) proves that they involve the working electrode material, i.e. iron. Besides, the high current densities (typically above $0.1 \mathrm{~A} / \mathrm{cm}^{2}$ ) evidence for fast reaction rates. Three oxidation peaks are observed, at around $1.2 \mathrm{~V} /\left(\mathrm{AlF}_{3}\right)$ $\mathrm{Al}), 1.35 \mathrm{~V} /\left(\mathrm{AlF}_{3} / \mathrm{Al}\right)$ and $1.85 \mathrm{~V} /\left(\mathrm{AlF}_{3} / \mathrm{Al}\right)$. The increase of current density leading to the first peak at $1.2 \mathrm{~V} /\left(\mathrm{AlF}_{3} / \mathrm{Al}\right)$ starts at $1.05 \mathrm{~V} /$ $\left(\mathrm{AlF}_{3} / \mathrm{Al}\right.$ ) (black dotted line). Below $1.05 \mathrm{~V} /\left(\mathrm{AlF}_{3} / \mathrm{Al}\right)$, lower oscillating currents are observed, starting from $0.9 \mathrm{~V} /\left(\mathrm{AlF}_{3} / \mathrm{Al}\right)$.

Similarly, current starts increasing from 1.0 and $1.4 \mathrm{~V} /\left(\mathrm{AlF}_{3} / \mathrm{Al}\right)$ for $\mathrm{Ni}$ and $\mathrm{Co}$ respectively, with a corresponding oxidation peak at 1.3 and $1.6 \mathrm{~V} /\left(\mathrm{AlF}_{3} / \mathrm{Al}\right)$. It can be noted that for $\mathrm{Ni}$, above the $\mathrm{O}_{2}$ evolution potential, a drastic drop of the current density is observed. It is likely due to the formation of an insulating $\mathrm{NiF}_{2}$ layer, as observed by Khramov [25]. 


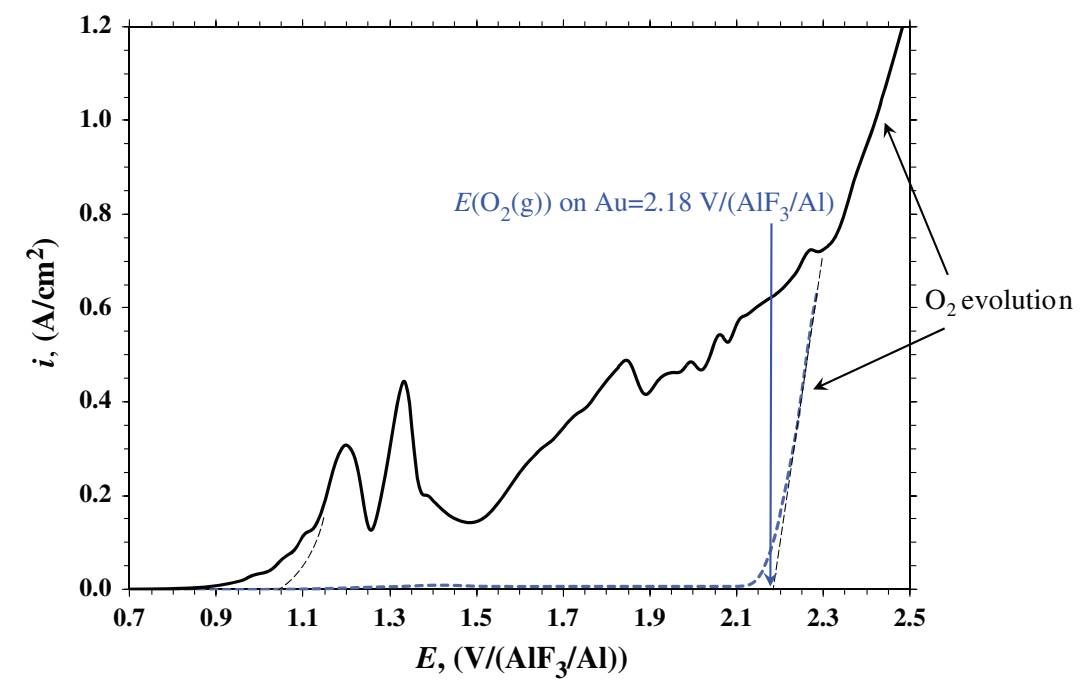

Fig. 1. Linear voltammograms (sweep rate $0.002 \mathrm{~V} / \mathrm{s}$ ) on iron (solid line) and gold (dotted line) in the $\mathrm{CAM}\left(\mathrm{CR}=2.2 ; 5 \mathrm{wt} . \% \mathrm{CaF}_{2} ; 9 \mathrm{wt} . \% \mathrm{Al}_{2} \mathrm{O}_{3} ; \mathrm{T}=960{ }^{\circ} \mathrm{C}\right.$ ).

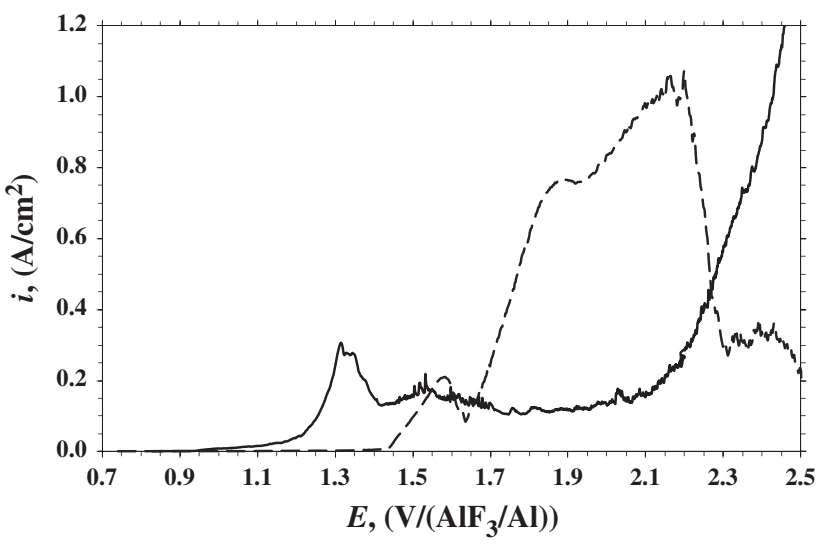

Fig. 2. Linear voltammograms (sweep rate $0.002 \mathrm{~V} / \mathrm{s}$ ) on cobalt (solid line) and nickel (dotted line) in the CAM $\left(\mathrm{CR}=2.2 ; 5 \mathrm{wt} . \% \mathrm{CaF}_{2} ; 9 \mathrm{wt} . \% \mathrm{Al}_{2} \mathrm{O}_{3} ; T=960{ }^{\circ} \mathrm{C}\right)$.

\subsubsection{Open circuit potential recordings after short polarization}

Measurements of the Open Circuit Potential (OCP) of iron, nickel and cobalt electrodes after a short anodic current pulse were performed in order to evidence the formation of an oxide layer on the electrode during the anodic polarization. Indeed, the appearance of a plateau during the relaxation following the current pulse indicates the presence of a solid compound on the electrode surface [4].

Several measurements were performed on the same sample, with sufficient relaxation time between each of them to allow the electrode potential to return to its initial equilibrium. The anodic applied current was progressively increased between each measurement.

Four of the open circuit potential recordings on iron are presented in Fig. 3.

As shown in Fig. 3, in the case of a low current density pulse $\left(0.02 \mathrm{~A} / \mathrm{cm}^{2}\right)$, the electrode potential returns directly to its rest value and no plateau is observed, even for longer current pulses (20 and $40 \mathrm{~s}$ ). The potential decay is not exponential but rather linear. This is attributed to side reactions, indicated by small oscillating currents on the linear voltammogram between 0.9 and $1.05 \mathrm{~V} /$ $\left(\mathrm{AlF}_{3} / \mathrm{Al}\right)$ (cf. Fig. 1).

After a $10 \mathrm{~s}$ anodic polarization at $0.26 \mathrm{~A} / \mathrm{cm}^{2}$, the electrode potential decreases through a plateau near $1.05 \mathrm{~V} /\left(\mathrm{AlF}_{3} / \mathrm{Al}\right)$, before dropping sharply to the initial value. This plateau indicates that a solid compound has formed on the surface and its pseudo-equilibrium potential is around $1.05 \mathrm{~V} /\left(\mathrm{AlF}_{3} / \mathrm{Al}\right)$.

Between these two values $\left(0.02\right.$ and $\left.0.26 \mathrm{~A} / \mathrm{cm}^{2}\right)$, the existence or not of the potential plateau during the relaxation is more ambiguous. For instance, as shown in Fig. 3 for $i=0.20 \mathrm{~A} / \mathrm{cm}^{2}$ and $t=10 \mathrm{~s}$, neither the potential returns directly to its rest value nor a stable plateau is observed: a slight wave takes place and does not allow concluding whether a solid compound was formed or not. This behavior may illustrate the early moments of the formation of the compound, with partial covering of the electrode surface.

Taking into account the ohmic drop IR due to the electrical resistance of the experimental set-up, the potentials reached during the polarization at 0.20 and $0.26 \mathrm{~A} / \mathrm{cm}^{2}$ are above the transient potential measured after the relaxation step $\left(E>E_{\text {plateau }}=1.05 \mathrm{~V} /\right.$ $\left.\left(\mathrm{AlF}_{3} / \mathrm{Al}\right)\right)$. Thus, the potential reached is not the only criterion, and it is proposed here that the formation of a solid compound on an iron electrode requires a minimal current density $\left(i_{\min }\right)$. A value around $0.20 \mathrm{~A} / \mathrm{cm}^{2}$ is a good estimate.

For pulse current densities higher than $0.20 \mathrm{~A} / \mathrm{cm}^{2}$ (for instance $i=0.55 \mathrm{~A} / \mathrm{cm}^{2}$ and $t=20 \mathrm{~s}$ on Fig. 3), a second potential plateau is observed at $1.14 \mathrm{~V} /\left(\mathrm{AlF}_{3} / \mathrm{Al}\right)$, suggesting the formation of a second oxidation product, at higher current densities and/or longer polarization times.

Concerning nickel and cobalt, open circuit potential plots are presented in Fig. 4.

They show the same trend as for iron. For low current pulses, the potential returns directly to its rest value. When increasing the pulse current, a minimal current density for which a plateau is observed during the relaxation is evidenced. For higher current densities, the plateau during the relaxation is clearly observed. For both nickel and cobalt, this limiting current density required to form a solid compound on the electrode surface was measured, and the estimated values for $i_{\min }$ and the corresponding plateau potential $\left(E_{\text {plateau }}\right)$ are summarized in Table 1.

\subsubsection{Electrolyses at constant potential}

To characterize the compounds formed at the metal electrode surface during the anodic polarization, potentiostatic electrolyses were performed on iron, cobalt and nickel. The potential values and corresponding charge imposed during the electrolyses are summarized in Table 2.

The characterization of the samples corresponding to these polarization conditions are presented in the following section. 

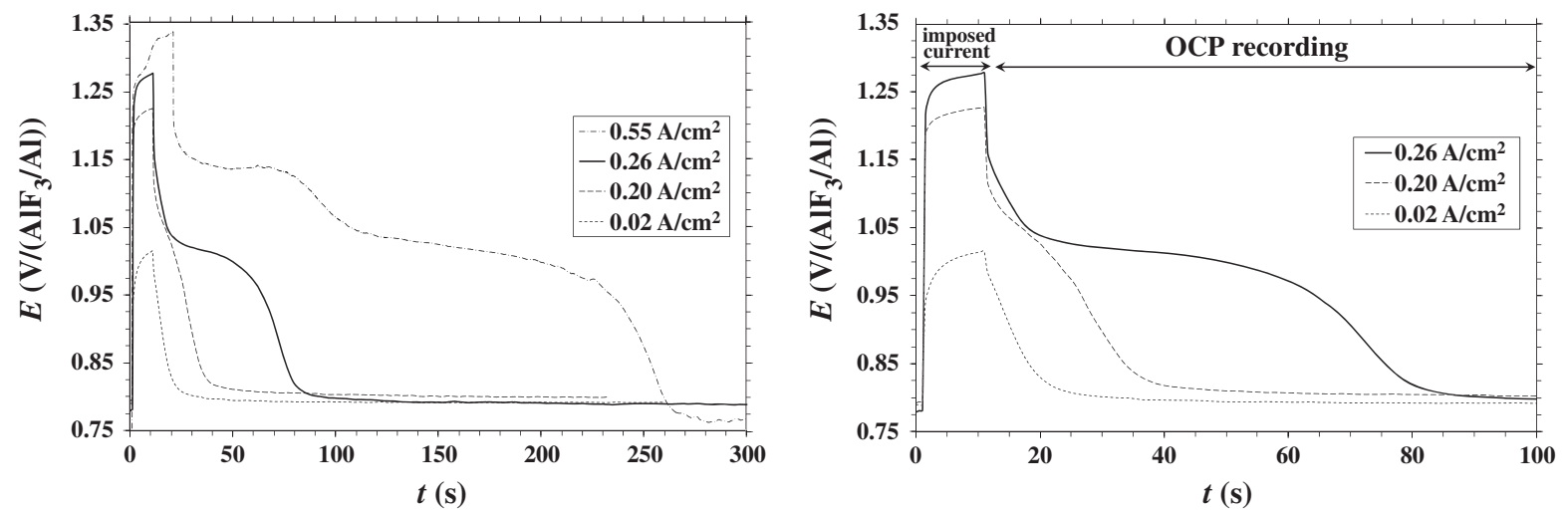

Fig. 3. Open circuit potential recordings obtained on an iron electrode after various current pulses in the $\mathrm{CAM}\left(\mathrm{CR}=2.2 ; 5\right.$ wt. $\left.\% \mathrm{CaF}_{2} ; 9 \mathrm{wt} . \% \mathrm{Al}_{2} \mathrm{O}_{3} ; \mathrm{T}=960{ }^{\circ} \mathrm{C}\right)(\mathrm{right}: \mathrm{zoom}$ of the left plot).
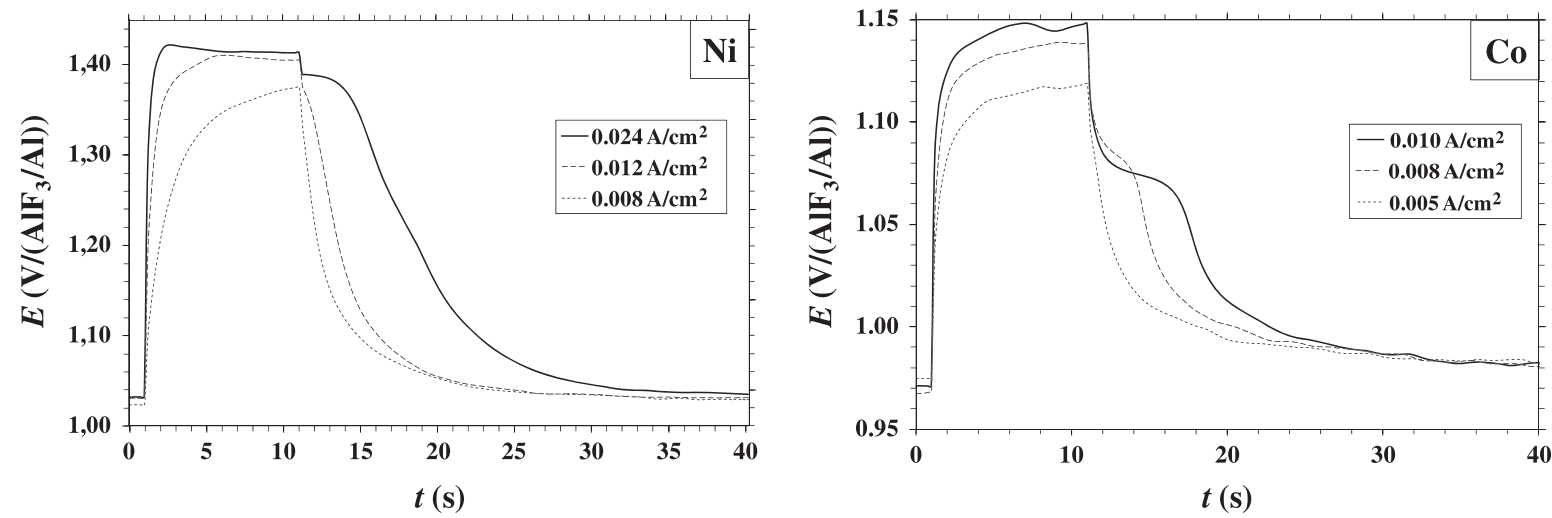

Fig. 4. Open circuit potential recordings obtained on nickel and cobalt electrodes after various current pulses in the $\mathrm{CAM}\left(\mathrm{CR}=2.2 ; 5\right.$ wt. $\%$ CaF $2 ; 9$ wt. $\left.\% \mathrm{Al}_{2} \mathrm{O}_{3} ; \mathrm{T}=960{ }^{\circ} \mathrm{C}\right)$.

Table 1

Values of $i_{\min }$ determined by OCP recordings after current pulses for different metals in the CAM $\left(\mathrm{CR}=2.2 ; 5 \mathrm{wt} . \% \mathrm{CaF}_{2} ; 9 \mathrm{wt} . \% \mathrm{Al}_{2} \mathrm{O}_{3} ; \mathrm{T}=960{ }^{\circ} \mathrm{C}\right)$.

\begin{tabular}{llll}
\hline Metal & $\mathrm{Fe}$ & $\mathrm{Ni}$ & $\mathrm{Co}$ \\
\hline$i_{\text {min }}\left(\mathrm{A} / \mathrm{cm}^{2}\right)$ & 0.200 & 0.012 & 0.008 \\
$E_{\text {plateau }}(\mathrm{V} / \mathrm{ref})$ & 1.05 & 1.39 & 1.10 \\
\hline
\end{tabular}

Table 2

Imposed potentials and charges during potentiostatic electrolyses on iron, cobalt and nickel in the CAM $\left(\mathrm{CR}=2.2 ; 5 \mathrm{wt} . \% \mathrm{CaF}_{2} ; 9 \mathrm{wt} . \% \mathrm{Al}_{2} \mathrm{O}_{3} ; \mathrm{T}=960{ }^{\circ} \mathrm{C}\right)$, immersed surface area: $\sim 0.25 \mathrm{~cm}^{2}$.

\begin{tabular}{lllll}
\hline Metal & $\begin{array}{l}\text { Imposed potential }(\mathrm{V}) \\
\left(\mathrm{AlF}_{3} / \mathrm{Al}\right)\end{array}$ & $\begin{array}{l}\text { Initial gold } \\
\text { markers }\end{array}$ & $\begin{array}{l}\text { Charge } \\
(\mathrm{C})\end{array}$ & $\begin{array}{l}\text { Duration } \\
(\mathrm{s})\end{array}$ \\
\hline Iron & 1.1 & No & 40 & 940 \\
Iron & 1.2 & Yes & 3 & 100 \\
Iron & 1.2 & Yes & 20 & 350 \\
Iron & 1.2 & No & 20 & 400 \\
Iron & 1.4 & No & 20 & 450 \\
Iron & 1.4 & No & 40 & 1000 \\
Cobalt & 1.4 & No & 1 & 1650 \\
Nickel & 1.5 & No & 5 & 100 \\
\hline
\end{tabular}

\subsection{Characterization after potentiostatic polarization on iron}

\subsubsection{Polarization at $1.1 \mathrm{~V} /\left(\mathrm{AlF}_{3} / \mathrm{Al}\right)(40 \mathrm{C})$}

SEM-BSE micrographs of the iron electrode after a potentiostatic polarization at $1.1 \mathrm{~V} /\left(\mathrm{AlF}_{3} / \mathrm{Al}\right)$ did not show the formation of any oxidation product on the electrode surface: only a frontal dissolution of the electrode occurred.

\subsubsection{Short time polarization at $1.2 \mathrm{~V} /\left(\mathrm{AlF}_{3} / \mathrm{Al}\right)(100 \mathrm{~s})$}

SEM-BSE micrograph of the iron electrode with the gold markers after a short $(100 \mathrm{~s})$ potentiostatic polarization at $1.2 \mathrm{~V} /\left(\mathrm{AlF}_{3} / \mathrm{Al}\right)$ is presented in Fig. $5 \mathrm{a}$.

This micrograph shows that a thin and adherent layer $(2-4 \mu \mathrm{m})$ was formed on the metal surface. Microprobe analysis indicates that the layer is composed of the elements $\mathrm{Fe}, \mathrm{Al}$ and $\mathrm{O}$, with an $(\mathrm{Al}+\mathrm{Fe}) / \mathrm{O}$ mole ratio of $0.76 \pm 0.03$ (11 measurements), evidencing a spinel phase $\left(\mathrm{Fe}, \mathrm{Al}_{3} \mathrm{O}_{4}\right.$. This aluminum ferrite has a composition between $\mathrm{AlFe}_{2} \mathrm{O}_{4}$ and $\mathrm{Al}_{0.7} \mathrm{Fe}_{2.3} \mathrm{O}_{4}$; it will henceforth be referred to as $\mathrm{Al}_{x} \mathrm{Fe}_{3-x} \mathrm{O}_{4}$.

It can be seen that the gold markers are embedded in the bulk of the ferrite phase, between the metal/ferrite and the ferrite/melt interfaces. In some places, small light grey nodules are visible between the metal and the ferrite layer. The microprobe analysis indicated that it corresponds to the wüstite phase, noted as $\mathrm{Fe}_{y} \mathrm{O}$ $(y<1)$.

\subsubsection{Longer time polarization at $1.2 \mathrm{~V} /\left(\mathrm{AlF}_{3} / \mathrm{Al}\right)(350 \mathrm{~s})$}

Fig. $5 \mathrm{~b}$ shows the SEM micrograph of an iron electrode after potentiostatic polarization at $1.2 \mathrm{~V} /\left(\mathrm{AlF}_{3} / \mathrm{Al}\right)$ for $350 \mathrm{~s}$. Again, a thin dark grey layer is observed at the interface with the electrolyte. The $(\mathrm{Al}+\mathrm{Fe}) / \mathrm{O}$ mole ratio in the layer, determined by microprobe analysis, is $0.77 \pm 0.03$ (14 measurements). Similar to the short polarization experiment, this layer is thus an aluminum ferrite phase. The gold markers which were initially present at the metal surface are not observed in this case. Under the aluminum ferrite layer, a $8-10 \mu \mathrm{m}$-thick layer of wüstite (light grey) is present with few pores localized at the metal/wüstite interface; the overall microstructure of the $\mathrm{Fe}_{y} \mathrm{O}$ layer is clearly dense and adherent. 

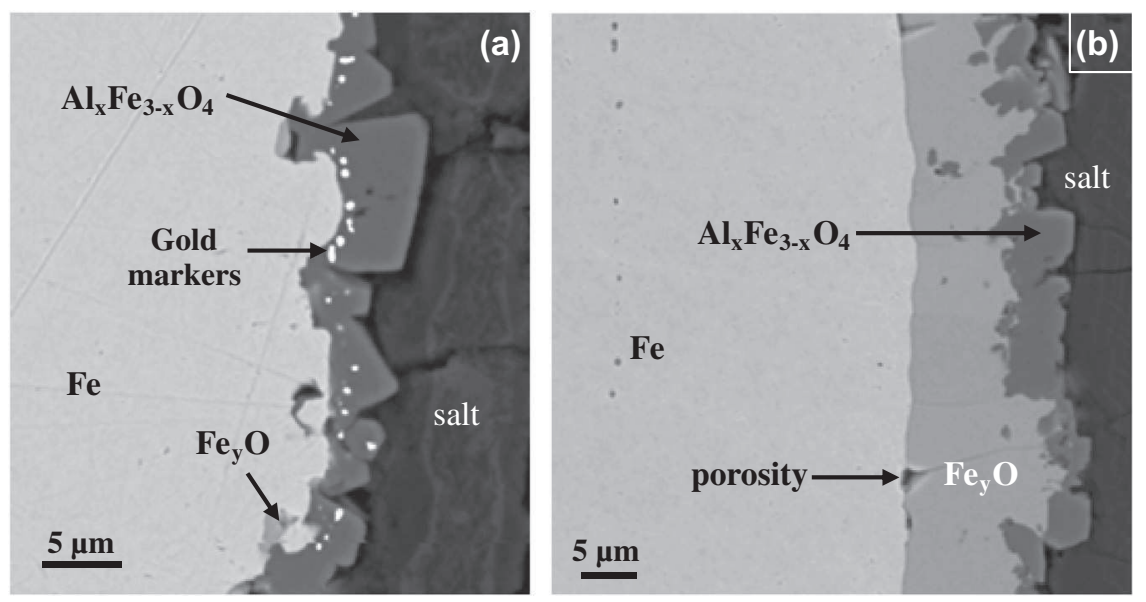

Fig. 5. SEM-BSE micrographs of an iron electrode (cross section) after polarization at $1.2 \mathrm{~V} /\left(\mathrm{AlF}_{3} / \mathrm{Al}\right)$ for $(\mathrm{a}) 100 \mathrm{~s}(3 \mathrm{C})$ and $(\mathrm{b}) 350 \mathrm{~s}(20 \mathrm{C})$ in the $\mathrm{CAM}(\mathrm{CR}=2.2 ; 5 \mathrm{wt} . \% \mathrm{CaF}$; 9 wt.\% $\mathrm{Al}_{2} \mathrm{O}_{3} ; T=960{ }^{\circ} \mathrm{C}$ ).

Besides, it can be noted that the metal/wüstite interface is very smooth, whereas the wüstite/ferrite interface is irregular, as is the metal/ferrite interface after short polarization at the same potential $(100 \mathrm{~s})$. Polarization under the same conditions (1.2 $\left.\mathrm{V} /\left(\mathrm{AlF}_{3} / \mathrm{Al}\right), 20 \mathrm{C}\right)$ was performed on an iron electrode without the initial gold markers. The same phases were seen with identical layer thicknesses, proving that the gold deposit does not influence oxide formation.

\subsubsection{Polarization at $1.4 \mathrm{~V} /\left(\mathrm{AlF}_{3} / \mathrm{Al}\right)$}

SEM-BSE micrographs of the iron electrode after potentiostatic polarization at $1.4 \mathrm{~V} /\left(\mathrm{AlF}_{3} / \mathrm{Al}\right)$ are presented in Fig. $6 \mathrm{a}$ and $\mathrm{b}$ for $20 \mathrm{C}$ and $40 \mathrm{C}$, respectively, together with elemental mapping (Al, O, Fe, F, Na).

The same sequence as after the $20 \mathrm{C}$-polarization at $1.2 \mathrm{~V} /\left(\mathrm{AlF}_{3} / \mathrm{Al}\right)$ is found along the electrode: salt $/ \mathrm{Al}_{x} \mathrm{Fe}_{3-x} \mathrm{O}_{4} / \mathrm{Fe}_{y} \mathrm{O} / \mathrm{Fe}$. The $\mathrm{Fe}_{y} \mathrm{O}$ and $\mathrm{Al}_{x} \mathrm{Fe}_{3-x} \mathrm{O}_{4}$ layers are thicker than after polarization at $1.2 \mathrm{~V} /\left(\mathrm{AlF}_{3} / \mathrm{Al}\right)$ for the same charge, but the main difference between the samples after the polarization at $1.2 \mathrm{~V} /\left(\mathrm{AlF}_{3} / \mathrm{Al}\right)$ and $1.4 \mathrm{~V} /\left(\mathrm{AlF}_{3} / \mathrm{Al}\right)$ for $20 \mathrm{C}$ concerns the porosity. Obviously, after the polarization at $1.2 \mathrm{~V} /\left(\mathrm{AlF}_{3} / \mathrm{Al}\right)$, the $\mathrm{Fe}_{y} \mathrm{O}$ layer is dense and adherent, whereas after the polarization at $1.4 \mathrm{~V} /\left(\mathrm{AlF}_{3} / \mathrm{Al}\right)$, numerous pores and voids filled with salt are observed, especially at the metal/ $\mathrm{Fe}_{y} \mathrm{O}$ interface and at the grain boundaries in the $\mathrm{Fe}_{y} \mathrm{O}$ layer. This phenomenon is even more pronounced for $40 \mathrm{C}$ : in some places the $\mathrm{Fe}_{y} \mathrm{O}$ layer is completely separated from the metal, and large amounts of salt have penetrated near to the metal surface where another very thin wüstite layer can be observed.

Elemental mapping confirms the chemical analyses: the bulk of $\mathrm{Fe}_{y} \mathrm{O}$ and $\mathrm{Al}_{x} \mathrm{Fe}_{3-x} \mathrm{O}_{4}$ layers are exempt of $\mathrm{Na}$ and $\mathrm{F}$, while most of the layers porosities are filled with salt (identified by the presence of $\mathrm{Al}, \mathrm{Na}$ and $\mathrm{F}$ elements). It is also clear from the elemental mapping presented in Fig. $6 \mathrm{~b}$ that Fe is not present in the infiltrated electrolyte or as a $\mathrm{FeF}_{x}$ solid compound.

Increasing the polarization voltage from 1.2 to $1.4 \mathrm{~V} /\left(\mathrm{AlF}_{3} / \mathrm{Al}\right)$ thus does not modify the oxide scale chemistry but greatly affects its microstructure and adhesion properties.

\subsection{Characterization after potentiostatic polarization on cobalt and nickel}

Typical SEM-BSE micrographs of cobalt and nickel electrodes after potentiostatic polarization are presented in Fig. 7a and b, respectively. For each metal, the potential was set above the potential $E_{\text {plateau }}$ observed in relaxation tests.
For both electrodes, the micrographs show that a biphasic layer has formed on the surface. Furthermore, the structure of each layer is the same as that formed on the iron electrode after polarization at $1.2 \mathrm{~V} /\left(\mathrm{AlF}_{3} / \mathrm{Al}\right)$ : a monoxide phase is evidenced on the metal surface ( $\mathrm{CoO}$ and $\mathrm{NiO}$ on the $\mathrm{Co}$ and $\mathrm{Ni}$ electrode, respectively), underneath an outer $\mathrm{Al}$-containing spinel phase $\left(\mathrm{Co}_{x} \mathrm{Al}_{3-x} \mathrm{O}_{4}\right.$ and $\mathrm{NiAl}_{2} \mathrm{O}_{4}$ on the $\mathrm{Co}$ and $\mathrm{Ni}$ electrode, respectively). It can be noted that the morphology of the monoxide layer on the nickel electrode is different from that on iron and cobalt: the latter look the same, but the nickel one is columnar. Although the experimental conditions were different for each metal (polarization potential, duration, charge), the same sequence was found: salt $/ \mathrm{M}_{x} \mathrm{Al}_{3-x} \mathrm{O}_{4} / \mathrm{M}_{y} \mathrm{O} / \mathrm{M}$, which very probably means that similar mechanisms are involved in the oxide layer formation.

\section{Thermodynamic calculations for iron}

In order to further understand experimental findings on iron, thermodynamic calculations were performed with the use of the FactSage 6.3 software [24] and the following databases: FactPS (pure substances), FToxid (spinel and monoxide solid solutions) and FThall ( $\mathrm{NaF}-\mathrm{AlF}_{3}-\mathrm{Al}_{2} \mathrm{O}_{3}-\mathrm{CaF}_{2}$ liquid solution). Since the FThall database does not include iron compounds, and since none of the $\mathrm{Na}-\mathrm{Ca}-\mathrm{F}$ elements were detected in the oxide layers formed on $\mathrm{Fe}$, it was decided to simulate the CAM with the unique compound $\mathrm{Al}_{2} \mathrm{O}_{3}$, which can account for both $\mathrm{Al}$ and $\mathrm{O}$ incorporation in the oxide layers. The system was thus restricted to the $\mathrm{Fe}-\mathrm{Al}_{2} \mathrm{O}_{3}-\mathrm{O}_{2}$ system, with $a\left(\mathrm{Al}_{2} \mathrm{O}_{3}\right)$ and $P\left(\mathrm{O}_{2}\right)$ as variables, while temperature $\left(960{ }^{\circ} \mathrm{C}\right), \mathrm{CR}(2.2)$ and total pressure $(1 \mathrm{~atm})$ were fixed.

In order to convert the calculated chemical potentials into electrochemical potentials, the following half-cell equation for the $\mathrm{O}_{2} / \mathrm{Al}_{2} \mathrm{O}_{3}$ redox system was considered:

$3 \mathrm{O}_{2(\mathrm{~g})}+4 \mathrm{AlF}_{3(\text { cry })}+12 \mathrm{Na}_{\text {(cry) }}^{+}+12 \mathrm{e}^{-}=2 \mathrm{Al}_{2} \mathrm{O}_{3(\text { cry })}+12 \mathrm{NaF}_{(\text {cry })}$

According to the Nernst equation, for reaction (1), the oxygen partial pressure $P\left(\mathrm{O}_{2}\right)$ is linked to the redox potential $E\left(\mathrm{O}_{2} / \mathrm{Al}_{2} \mathrm{O}_{3}\right)$ according to:

$$
\begin{aligned}
E\left(\mathrm{O}_{2} / \mathrm{Al}_{2} \mathrm{O}_{3}\right)= & E^{0}\left(\mathrm{O}_{2} / \mathrm{Al}_{2} \mathrm{O}_{3}\right)+\frac{2 \cdot 303 R T}{12 F} \\
& \times \log \left[\frac{P^{3}\left(\mathrm{O}_{2}\right) \cdot a^{4}\left(\mathrm{AlF}_{3}\right) \cdot a^{12}\left(\mathrm{Na}^{+}\right)}{a^{2}\left(\mathrm{Al}_{2} \mathrm{O}_{3}\right) \cdot a^{12}(\mathrm{NaF})}\right]
\end{aligned}
$$

where: 

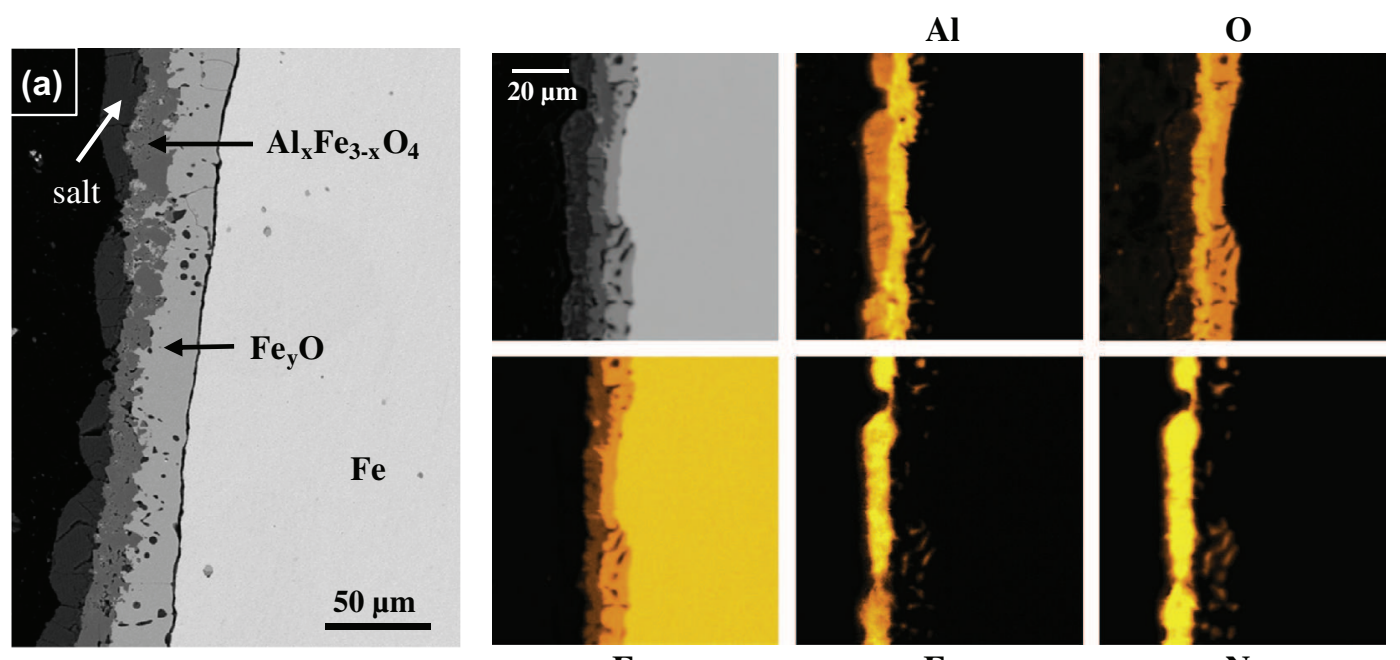

$\mathrm{Fe}$

$\mathbf{F}$

$\mathrm{Na}$
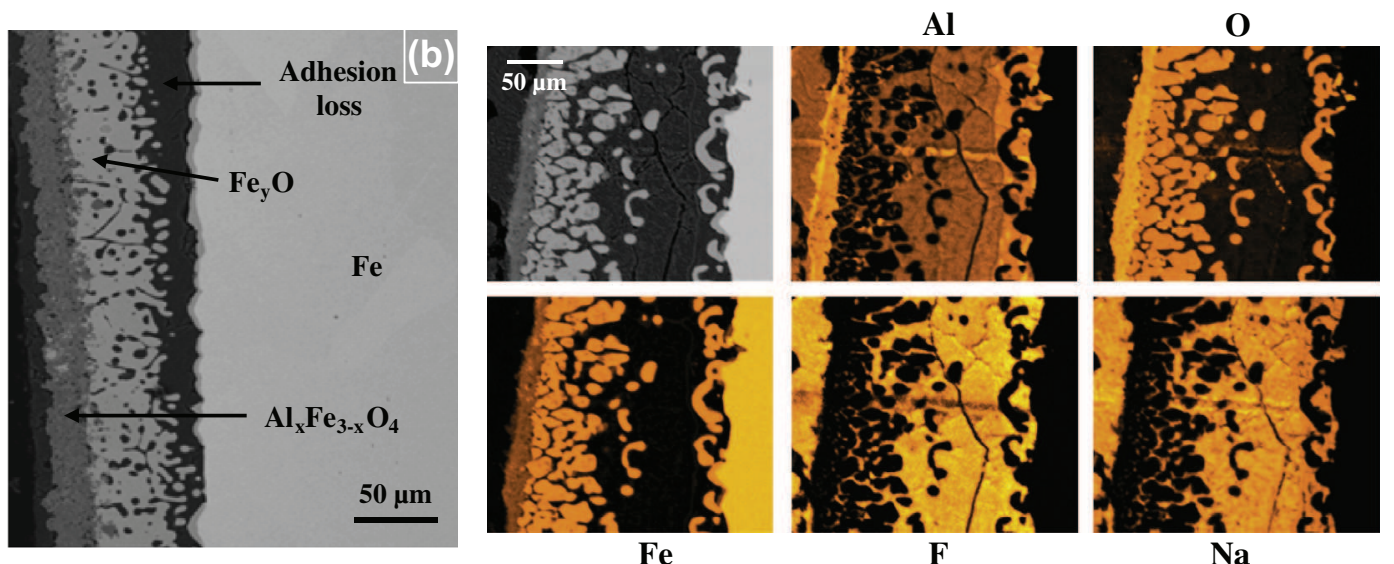

Fig. 6. SEM-BSE micrographs and elemental mapping of an iron electrode (cross section) after polarization at $1.4 \mathrm{~V} /(\mathrm{AlF} / \mathrm{Al})$ for $(\mathrm{a}) 450 \mathrm{~s}(20 \mathrm{C})$ and $(\mathrm{b}) 1000 \mathrm{~s}(40 \mathrm{C})$ in the CAM (CR $=2.2 ; 5$ wt.\% $\mathrm{CaF}_{2} ; 9$ wt.\% $\left.\mathrm{Al}_{2} \mathrm{O}_{3} ; T=960{ }^{\circ} \mathrm{C}\right)$.
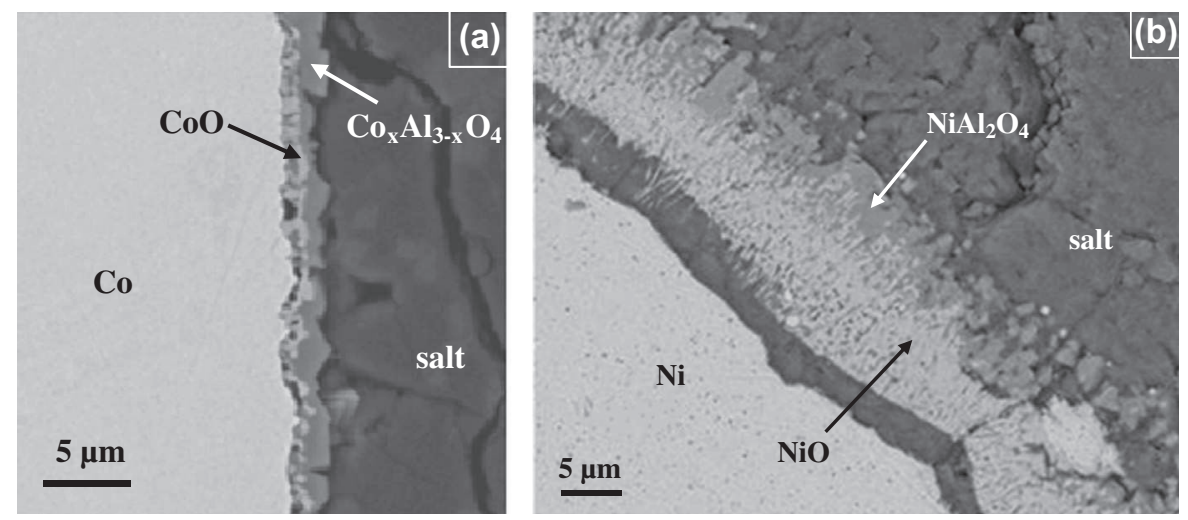

Fig. 7. SEM-BSE micrographs (cross sections) of (a) a cobalt electrode after polarization at $1.35 \mathrm{~V} /\left(\mathrm{AlF}_{3} / \mathrm{Al}\right)$ for $1600 \mathrm{~s}(1 \mathrm{C})$ and (b) a nickel electrode after polarization at $1.50 \mathrm{~V} /\left(\mathrm{AlF}_{3} / \mathrm{Al}\right)$ for $100 \mathrm{~s}(4.8 \mathrm{C})$ in the $\mathrm{CAM}\left(\mathrm{CR}=2.2 ; 5 \mathrm{wt} . \% \mathrm{CaF}_{2} ; 9 \mathrm{wt} . \% \mathrm{Al}_{2} \mathrm{O}_{3} ; T=960{ }^{\circ} \mathrm{C}\right)$.

(i) $a\left(\mathrm{AlF}_{3}\right), a(\mathrm{NaF})$ and $a\left(\mathrm{Al}_{2} \mathrm{O}_{3}\right)$ refer to the activity of the compounds considering $\mathrm{AlF}_{3}(\mathrm{~s} 2), \mathrm{Al}_{2} \mathrm{O}_{3}(\gamma, \mathrm{s})$ and $\mathrm{NaF}(\mathrm{s})$ as reference states, respectively,

(ii) the activity of $\mathrm{Na}^{+}, a\left(\mathrm{Na}^{+}\right)$, is assumed to be unity,

(iii) $R$ is the ideal gas constant, $T$ the absolute temperature $(\mathrm{K})$ and $F$ the Faraday constant $\left(\mathrm{C} \mathrm{mol}^{-1}\right)$, (iv) $E^{\circ}\left(\mathrm{O}_{2} / \mathrm{Al}_{2} \mathrm{O}_{3}\right)$ is the standard potential, considering the redox couple $\mathrm{AlF}_{3} / \mathrm{Al}$ as the reference potential (i.e. $E^{\circ}\left(\mathrm{AlF}_{3} /\right.$ $\mathrm{Al})=0 \mathrm{~V})$.

With the operating experimental conditions, preliminary calculations showed that: 
(i) $E^{\circ}\left(\mathrm{O}_{2} / \mathrm{Al}_{2} \mathrm{O}_{3}\right)=2.218 \mathrm{~V}$ vs. $\mathrm{AlF}_{3} / \mathrm{Al}$ at $960^{\circ} \mathrm{C}$,

(ii) $a\left(\mathrm{AlF}_{3}\right)=0.0019$ and $a(\mathrm{NaF})=0.1884$ for a cryolite mixture of $\mathrm{CR}=2.2$ containing $5 \mathrm{wt} . \% \mathrm{CaF}_{2}$ at $960^{\circ} \mathrm{C}$. The variation of $\mathrm{AlF}_{3}$ and $\mathrm{NaF}$ activities with the $\mathrm{Al}_{2} \mathrm{O}_{3}$ content was considered negligible. These activity data are in good agreement with data published by Solheim et al. [26].

The relationship between $E\left(\mathrm{O}_{2} / \mathrm{Al}_{2} \mathrm{O}_{3}\right)$ and $P\left(\mathrm{O}_{2}\right)$ is finally:

$$
\begin{aligned}
E\left(\mathrm{O}_{2} / \mathrm{Al}_{2} \mathrm{O}_{3}\right)= & 2.174+0.061 \log \left[P\left(\mathrm{O}_{2}\right)\right]-0.041 \\
& \times \log \left[a\left(\mathrm{Al}_{2} \mathrm{O}_{3}\right)\right]
\end{aligned}
$$

\subsection{Composition-potential diagram}

A composition-potential diagram, presented in Fig. 8, was first established for $a\left(\mathrm{Al}_{2} \mathrm{O}_{3}\right)=1$, accounting for an alumina-saturated cryolite mixture. It shows the stable phases in the $\mathrm{Fe}-\mathrm{O}_{2}-\mathrm{Al}_{2} \mathrm{O}_{3}$ system as a function of potential and the proportion of each element in the spinel phase when increasing potential from $1.00 \mathrm{~V} /$ $\left(\mathrm{AlF}_{3} / \mathrm{Al}\right)$ up to $2.25 \mathrm{~V} /\left(\mathrm{AlF}_{3} / \mathrm{Al}\right)$.

Iron starts oxidizing and forms an iron aluminate whose composition is $\mathrm{FeAl}_{2} \mathrm{O}_{4}$ at $1.11 \mathrm{~V} /\left(\mathrm{AlF}_{3} / \mathrm{Al}\right)$. Then, the phase composition evolves from $\mathrm{FeAl}_{2} \mathrm{O}_{4}$ to $\mathrm{Fe}_{3} \mathrm{O}_{4}$. Over $1.82 \mathrm{~V} /\left(\mathrm{AlF}_{3} / \mathrm{Al}\right)$, the spinel phase oxidizes into the $\mathrm{Fe}_{2} \mathrm{O}_{3}$ hematite phase. At $E=2.174 \mathrm{~V}$, $\mathrm{O}_{2}(\mathrm{~g})$ is stable together with $\mathrm{Fe}_{2} \mathrm{O}_{3}$.

\subsection{Potential-alumina activity diagram}

The stability diagram of the $\mathrm{Fe}-\mathrm{O}_{2}-\mathrm{Al}_{2} \mathrm{O}_{3}$ system versus potential and alumina activity is presented in Fig. 9. On this diagram, for $a\left(\mathrm{Al}_{2} \mathrm{O}_{3}\right)=1$, the same evolution as plotted in Fig. 8 is found: iron oxidation starts at $1.11 \mathrm{~V} /\left(\mathrm{AlF}_{3} / \mathrm{Al}\right)$, with the formation of a $\mathrm{Fe}_{x} \mathrm{Al}_{3-x} \mathrm{O}_{4}$ spinel phase, leading to the $\mathrm{Fe}_{2} \mathrm{O}_{3}$ formation at $1.82 \mathrm{~V} /$ $\left(\mathrm{AlF}_{3} / \mathrm{Al}\right)$. However, for lower alumina activities (e.g. $a\left(\mathrm{Al}_{2} \mathrm{O}_{3}\right)$ $<0.11$ ), the existence of a stable $\mathrm{Fe}_{y} \mathrm{O}$ phase is evidenced between 1.26 and $1.43 \mathrm{~V} /\left(\mathrm{AlF}_{3} / \mathrm{Al}\right)$.

\subsection{Iron-substoichiometry in $\mathrm{Fe}_{y} \mathrm{O}$ as a function of $E(V)$}

The diagram presented in Fig. 9 defines a range of potentials and alumina activities where wüstite is the stable phase. Studies on the high temperature oxidation behavior of pure iron in air showed that the wüstite phase is a p-type iron-deficient semiconductor, which can exist over a wide range of stoichiometry, from

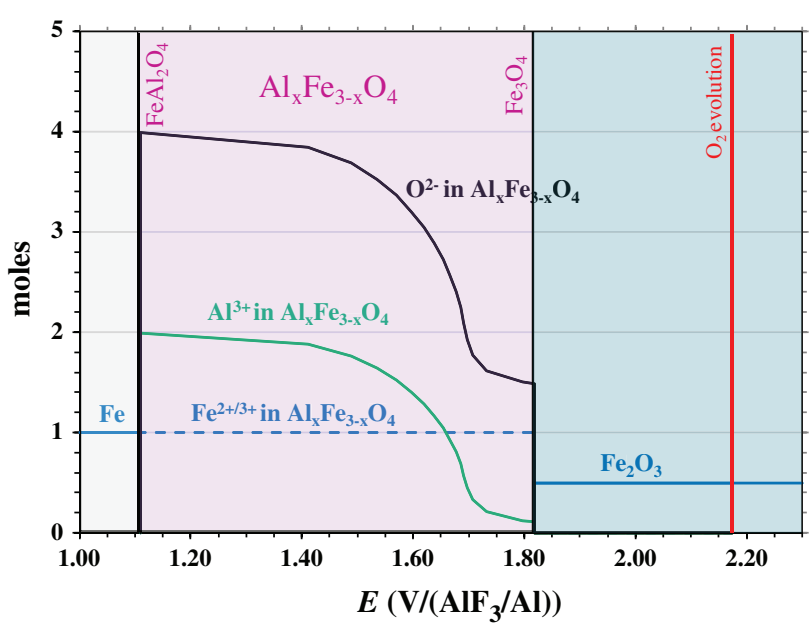

Fig. 8. Composition-potential diagram for the $\mathrm{Fe}-\mathrm{O}_{2}-\mathrm{Al}_{2} \mathrm{O}_{3}$ system, with $1 \mathrm{~mol}$ of $\mathrm{Fe}$, at $T=960^{\circ} \mathrm{C}, a\left(\mathrm{Al}_{2} \mathrm{O}_{3}\right)=1, \mathrm{CR}=2.2$.

$\mathrm{Fe}_{0.95} \mathrm{O}$ to $\mathrm{Fe}_{0.88} \mathrm{O}$ at $1000{ }^{\circ} \mathrm{C}$ [27]. Since Eq. (3) shows that the applied potential and oxygen partial pressure are related, the $\mathrm{Fe}_{y} \mathrm{O}$ stoichiometry is expected to vary with the potential. Thus, a " $E\left(\mathrm{~V} /\left(\mathrm{AlF}_{3} / \mathrm{Al}\right)\right)-\mathrm{Fe}_{y} \mathrm{O}$ composition" diagram was calculated (for $\log \left[a\left(\mathrm{Al}_{2} \mathrm{O}_{3}\right)\right]=-1.8$, cf. dotted line in Fig. 9) to exhibit the influence of the potential on the $\mathrm{Fe}_{y} \mathrm{O}$ composition change. This diagram is presented in Fig. 10.

The diagram shows that the Fe/O molar ratio in the wüstite phase varies linearly with the applied potential during the polarization. Indeed, the higher the potential applied, the lower the iron content in $\mathrm{Fe}_{y} \mathrm{O}$, i.e. the higher the cation vacancy concentration.

\section{Discussion}

The understanding of oxidation mechanisms that can be inferred from both experimental and thermodynamic studies is proposed in the following section.

\subsection{Oxidation mechanisms on Fe}

\subsubsection{Formation of the aluminum ferrite layer}

According to the linear voltammetry measurements, the first reaction involving iron starts around $1.05 \mathrm{~V} /\left(\mathrm{AlF}_{3} / \mathrm{Al}\right)$ with the oxidation of metallic iron into $\mathrm{Fe}(\mathrm{II})$. It can be noted that there is a

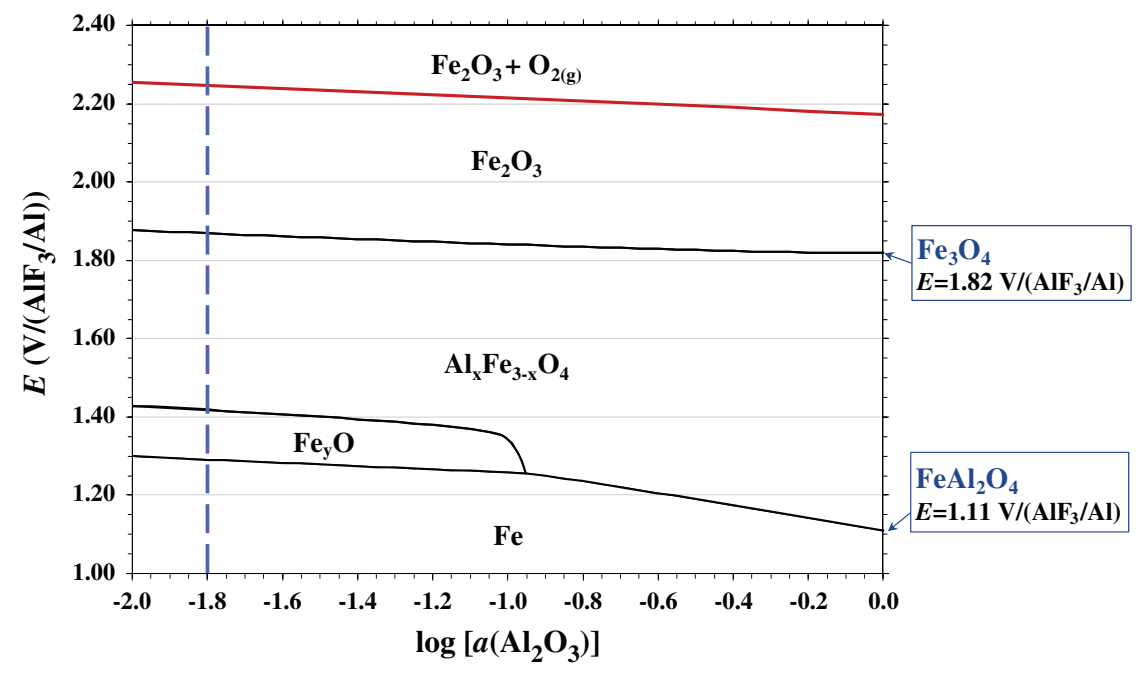

Fig. 9. Potential-alumina activity diagram for the $\mathrm{Fe}-\mathrm{O}_{2}-\mathrm{Al}_{2} \mathrm{O}_{3}$ system at $\mathrm{T}=960{ }^{\circ} \mathrm{C}, \mathrm{CR}=2.2$. 


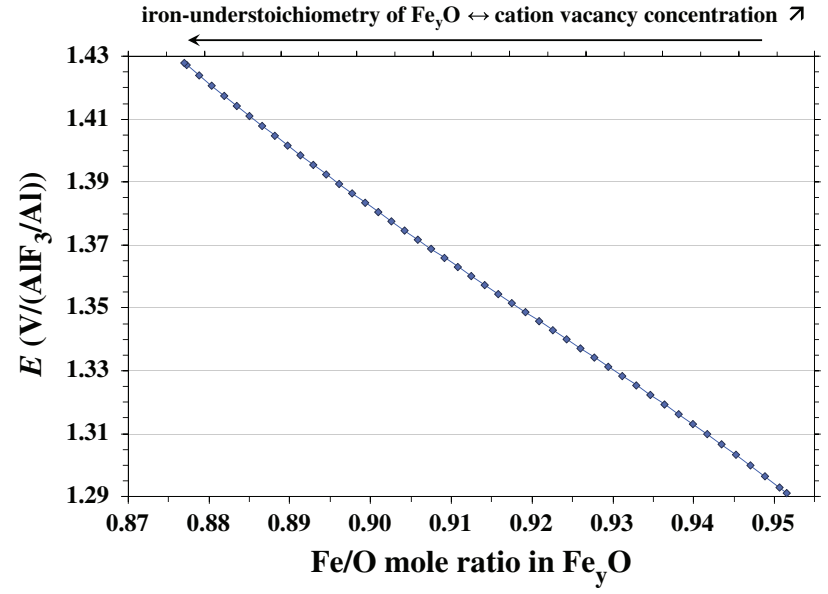

Fig. 10. Variation of the iron-substoichiometry of $\mathrm{Fe}_{\mathrm{y}} \mathrm{O}$ with $P\left(\mathrm{O}_{2}\right), \log \left[a\left(\mathrm{Al}_{2} \mathrm{O}_{3}\right)\right]=-$ $1.8, C R=2.2$.

slight difference between the measured potential and the potential given by the thermodynamic calculations $\left(1.11 \mathrm{~V} /\left(\mathrm{AlF}_{3} / \mathrm{Al}\right)\right)$ : this is attributed to iron dissolution in the CAM. Indeed, this dissolution leads to a depolarization, involving solvation effects [28], which is not taken into account in the calculations since the thermochemical databases do not include iron compounds dissolved in the CAM.

The OCP recordings show that after a short current pulse at a low current density (below $0.2 \mathrm{~A} / \mathrm{cm}^{2}$ ), no potential plateau is observed during the relaxation, even if the potential reached during the polarization is above the $E_{\text {plateau }}$ equilibrium potential measured during the relaxation. This indicates that no stable phase has formed on the anode surface. To observe a plateau during relaxation, current density must reach a minimal value $\left(i_{\text {min }}\right)$. Thus, the applied potential is not the only criterion, current density also has an influence: a minimal current density estimated around $0.20 \mathrm{~A} / \mathrm{cm}^{2}$ is required to form the $\mathrm{Fe}_{x} \mathrm{Al}_{3-x} \mathrm{O}_{4}$ layer.

The existence of this limiting current density can be explained considering that a minimal iron flux from the metal towards the melt is required to saturate the melt with $\mathrm{Fe}(\mathrm{II})$ at the interface and form the $\mathrm{Fe}_{x} \mathrm{Al}_{3-x} \mathrm{O}_{4}$ phase. Indeed, as shown by Jentoftsen [22], when the $\mathrm{Fe}(\mathrm{II})$ concentration reaches the solubility limit in a CAM, a $\mathrm{FeAl}_{2} \mathrm{O}_{4}$ iron aluminate phase forms. As long as this solubility limit is not reached, $\mathrm{Fe}(\mathrm{II})$ species remain dissolved in the melt and the iron aluminate does not form. As an example, the $\mathrm{Fe}(\mathrm{II})$ solubility limit in a cryolite melt saturated with alumina, for $T=1020^{\circ} \mathrm{C}$ and $\mathrm{CR}=2.3$, is $0.34 \mathrm{wt} . \%$. Thus, to form the iron aluminate, the iron flux from the metal, i.e. the dissolution current, must be high enough to saturate the interface with $\mathrm{Fe}(\mathrm{II})$. If not, the $\mathrm{Fe}(\mathrm{II})$ dilutes from the surface into the melt due to convection, and the aluminate does not form since the electrolyte near the surface does not reach saturation.

According to this assumption, the first step of the iron oxidation mechanism which leads to the formation of an outer layer is a metal dissolution/spinel precipitation phenomenon. The SEM characterization of an iron electrode after short polarization at $1.2 \mathrm{~V} /\left(\mathrm{AlF}_{3} / \mathrm{Al}\right)(3 \mathrm{C})$ confirmed this hypothesis (Fig. 5a). First of all, on the iron surface, an $\mathrm{Fe}_{x} \mathrm{Al}_{3-x} \mathrm{O}_{4}$ aluminum ferrite layer has formed, in agreement with the thermodynamic calculations. Besides, the gold markers position in this layer indicates that the growth is neither inwards nor outwards. Indeed, these markers, initially situated at the iron surface, are observed inside the ferrite layer.

In the case of an inward growth of this layer by inward oxide ions flow, these gold markers would have been at the ferrite/melt interface, and in the case of an outward growth by outward cations flow, they would have been at the metal/ferrite interface. Thus, their intermediate position in the bulk suggests that first the metal dissolves quickly: the $\mathrm{Fe}(\mathrm{II})$ dissolved and the gold markers stay in the electrolyte near to the surface. Then, when saturation is reached, they precipitate with the $\mathrm{Al}(\mathrm{III})$ and $\mathrm{O}(-\mathrm{II})$ from the electrolyte to form the ferrite layer which traps the gold markers.

This metal dissolution/ferrite precipitation phenomenon is illustrated in Fig. 11a and b.

The SEM characterization of an iron electrode after longer polarization at $1.2 \mathrm{~V} /\left(\mathrm{AlF}_{3} / \mathrm{Al}\right)(20 \mathrm{C})$, the disappearance of the gold markers in the aluminum ferrite layer and the fact that the thickness of the layer remains quite constant suggest that the ferrite dissolves and regenerates at about the same rate.

\subsubsection{Growth of the $\mathrm{Fe}_{y} \mathrm{O}$ layer}

Once the ferrite layer has precipitated on the iron surface, the next step in the oxidation process is the formation of an intermediate $\mathrm{Fe}_{y} \mathrm{O}$ layer, between the metal and the aluminum ferrite layer. The SEM characterization of an iron electrode after short polarization at $1.2 \mathrm{~V} /\left(\mathrm{AlF}_{3} / \mathrm{Al}\right)(3 \mathrm{C})$ showed small nodules of $\mathrm{Fe}_{y} \mathrm{O}$ in some places at the metal/ferrite interface. After longer polarization at $1.2 \mathrm{~V} /\left(\mathrm{AlF}_{3} / \mathrm{Al}\right)(20 \mathrm{C})$, these nodules turned into a dense and adherent $\mathrm{Fe}_{y} \mathrm{O}$ layer.

According to thermodynamic calculations (cf. Fig. 9), the $\mathrm{Fe}_{y} \mathrm{O}$ phase is stable only between 1.26 and $1.43 \mathrm{~V} /\left(\mathrm{AlF}_{3} / \mathrm{Al}\right)$, for an alumina activity in the CAM below 0.11 . The fact that this phase is observed in our experimental conditions (alumina-saturated melt) means that the ferrite layer acts as a shield against the species from the CAM and that underneath this layer, the alumina activity is low enough to allow $\mathrm{Fe}_{y} \mathrm{O}$ formation between the metal and the $\mathrm{Al}_{x} \mathrm{Fe}_{3}-$ ${ }_{-x} \mathrm{O}_{4}$ phases.

Besides, even if a few pores are observed at the metal $/ \mathrm{Fe}_{y} \mathrm{O}$ layer interface, the overall microstructure of the layer is clearly dense and adherent. It indicates that the $\mathrm{Fe}_{y} \mathrm{O}$ layer grows inwards principally. Indeed, the case of a growth predominantly outwards, based on an iron flux towards the CAM, would imply creation of vacancies at the metal/ $\mathrm{Fe}_{y} \mathrm{O}$ layer interface, and thus lead to loss of adhesion of the layer by formation of pores. It was concluded that the $\mathrm{Fe}_{y} \mathrm{O}$ layer grows mainly inwards, due to $\mathrm{O}^{2-}$ diffusion from the CAM to the metal/ $\mathrm{Fe}_{y} \mathrm{O}$ layer interface via grain boundaries. This mechanism is illustrated in Fig. 11.

\subsubsection{Degradation of the $\mathrm{Fe}_{y} \mathrm{O}$ layer}

In contrast to the dense and adherent microstructure observed at $1.2 \mathrm{~V} /\left(\mathrm{AlF}_{3} / \mathrm{Al}\right)$, polarization at $1.4 \mathrm{~V} /\left(\mathrm{AlF}_{3} / \mathrm{Al}\right)$ leads to a $\mathrm{Fe}_{y} \mathrm{O}$ layer containing numerous pores and voids filled with salt, especially at the metal $/ \mathrm{Fe}_{y} \mathrm{O}$ interface and at the grain boundaries in the $\mathrm{Fe}_{y} \mathrm{O}$ layer. A loss of adherence of the $\mathrm{Fe}_{y} \mathrm{O}$ layer was observed. The presence of pores indicates iron diffusion from the metal/oxide interface towards the melt, creating pores and voids, which reveals a change in the oxidation mechanism.

In the wüstite phase, the $\mathrm{Fe}(\mathrm{II})$ mobility and thus its diffusion rate is related to the cation vacancy concentration: high cation vacancy concentration implies high cation mobility [27]. Thermodynamic calculations have shown that the iron-substoichiometry of $\mathrm{Fe}_{y} \mathrm{O}$ increases with the applied potential, from $\mathrm{Fe}_{0.95} \mathrm{O}$ to $\mathrm{Fe}_{0.88} \mathrm{O}$ (cf. Fig. 10): the higher the potential applied, the higher the diffusion rate of $\mathrm{Fe}(\mathrm{II})$ in $\mathrm{Fe}_{y} \mathrm{O}$.

As a consequence, at low potentials, the cation mobility in the $\mathrm{Fe}_{y} \mathrm{O}$ phase is low, and the $\mathrm{O}^{2-}$ diffusion from the CAM to the me$\mathrm{tal} / \mathrm{Fe}_{y} \mathrm{O}$ interface by grain boundaries is the predominant mechanism for the oxidation process: the $\mathrm{Fe}_{y} \mathrm{O}$ growth is mainly inwards, and the layer formed is adherent. On the contrary, at higher potentials, the $\mathrm{Fe}_{y} \mathrm{O}$ iron-substoichiometry is high, and so is the $\mathrm{Fe}(\mathrm{II}) / \mathrm{Fe}(\mathrm{III})$ mobility in the wüstite layer. It has been assumed that the ferrite layer dissolves and regenerates at about the same rate. This assumption is in agreement with the increase 


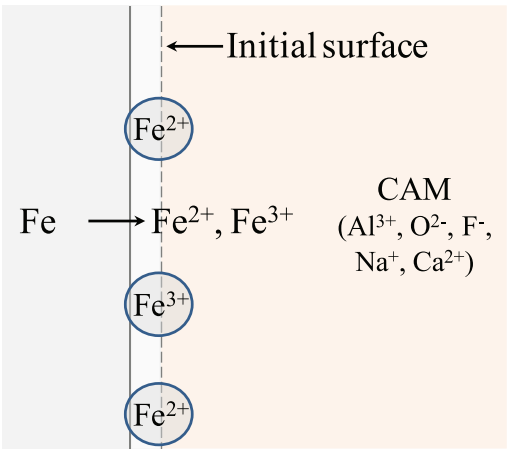

(a) Iron dissolution and increase of the $\mathrm{Fe}^{2+}, \mathrm{Fe}^{3+}$ concentration

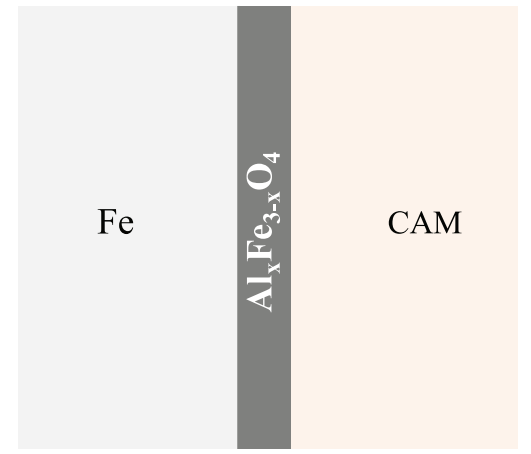

(b) Saturation in $\mathrm{Fe}^{2+}, \mathrm{Fe}^{3+}$ and precipitation of the $\mathrm{Al}_{\mathrm{x}} \mathrm{Fe}_{3-\mathrm{x}} \mathrm{O}_{4}$ layer

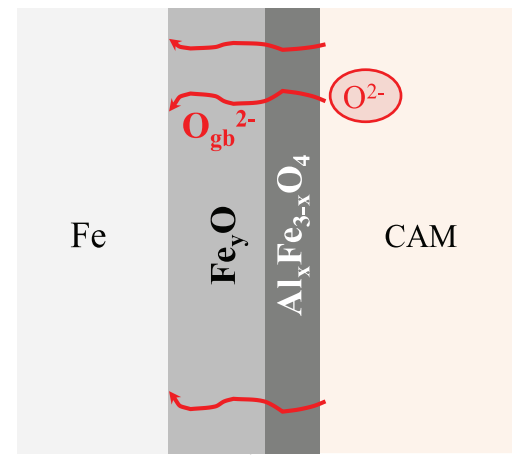

(c) $\mathrm{O}^{2-}$ diffusion at the grain boundaries and inward growth of $\mathrm{Fe}_{\mathrm{y}} \mathrm{O}$

Fig. 11. Summary of oxide layer formation mechanism on iron at low potentials: metal dissolution (a), ferrite precipitation (b), wüstite growth (c).

of the $\mathrm{Fe}(\mathrm{II}) / \mathrm{Fe}(\mathrm{III})$ mobility in the wüstite phase. Indeed, due to their higher mobility, $\mathrm{Fe}(\mathrm{II})$ and $\mathrm{Fe}(\mathrm{III})$ diffuse from the wüstite layer into the ferrite phase where they participate in the formation of the ferrite phase, whose thickness remains about constant due to its dissolution in the electrolyte at the same time. This diffusion leads to the creation of pores and voids in the wüstite layer, especially at the metal/wüstite interface, and at the grain boundaries where the diffusion rate is higher.

Unlike the results of Gallino [18], Khramov [25] and Beck [29], no $\mathrm{FeF}_{x}$ phase is observed at the metal/oxide interface or in the infiltrated salt. This is attributed to the short polarization time (maximum $1000 \mathrm{~s}$ compared to at least $72 \mathrm{~h}$ in the other studies), not long enough to allow iron fluoride formation. It is thus believed that the metal fluoride formation occurs in a later stage of the degradation process, after the initial formation of the two oxide layers, and when no oxide ion is available anymore in the infiltrated electrolyte.

\subsection{Oxidation mechanisms on nickel and cobalt}

Experimental results obtained on nickel and cobalt showed the same phenomena as those obtained with iron. First of all, open circuit potential recordings after short polarization showed the existence of a minimal current density $i_{\text {min }}$ required to form a stable compound on the electrode surface. Then, the same type of layer was observed on the electrode surface after low potential polarization: an Al-containing spinel at the interface with the CAM, above a monoxide phase layer near to the metal. Thus, the same oxidation scenario is proposed for iron, nickel and cobalt: metal dissolution/ spinel precipitation/monoxide growth.

However, $i_{\min }$ was observed to vary from one metal to another: it decreases following the sequence $\mathrm{Fe}>\mathrm{Ni}>\mathrm{Co}$. This variation is similar to the metal ions $\mathrm{M}^{\mathrm{n}+}$ solubility in the CAM. Indeed, for iron, it has been proposed that the minimal current density $i_{\min }$ corresponds to a minimum $\mathrm{Fe}(\mathrm{II}) / \mathrm{Fe}(\mathrm{III})$ flux, from the metal towards the melt, required to saturate the melt at the interface and precipitate the $\mathrm{Fe}_{x} \mathrm{Al}_{3-x} \mathrm{O}_{4}$ phase. Likewise, it is proposed here that the value of $i_{\min }$ for $\mathrm{Ni}$ (respectively $\mathrm{Co}$ ) corresponds to a minimum flux required to precipitate the $\mathrm{NiAl}_{2} \mathrm{O}_{4}$ (respectively $\mathrm{Co}_{x} \mathrm{Al}_{3-x} \mathrm{O}_{4}$ ) phase.

Literature data [22] indicates that in similar experimental conditions $\left(\mathrm{CR}=2.3, \mathrm{Al}_{2} \mathrm{O}_{3}\right.$-saturated $\left.\mathrm{CAM}, \mathrm{T}=1020^{\circ} \mathrm{C}\right)$, the $\mathrm{Fe}(\mathrm{II})$ solubility is $0.34 \mathrm{wt} \%$ and that of $\mathrm{Ni}(\mathrm{II})$ is $0.0025 \mathrm{wt} . \%$. This is in agreement with the fact that $i_{\min }$ for Fe is much higher than for $\mathrm{Ni}\left(0.20-0.25 \mathrm{~A} / \mathrm{cm}^{2}\right.$ compared to $\left.0.012 \mathrm{~A} / \mathrm{cm}^{2}\right)$. No data is available concerning the Co solubility in CAM, but since $i_{\text {min }}(\mathrm{Fe})>i_{\text {min }}(\mathrm{Ni})>i_{\text {min }}(\mathrm{Co})$, it is expected that the solubility of Co compounds is even lower than that of $\mathrm{Ni}$.
Thus, for each metal, $i_{\min }(\mathrm{M})$ depends on the $\mathrm{M}^{\mathrm{n}+}$ concentration required to saturate the melt in a small volume of salt at the metal surface: the lower the concentration to reach, the lower the metallic ion flux, thus the lower the current density required for the same polarization time.

\section{Conclusions}

The study of the anodic behavior of iron, cobalt and nickel in cryolitic melt during low potential polarization yields relevant information on the oxidation reactions occurring, depending on the polarization conditions, and allows proposing a common oxidation scenario: metal dissolution/spinel precipitation/monoxide growth.

When the potential is above $E\left(\mathrm{M} / \mathrm{M}^{\mathrm{n}+}\right)$, the metal $\mathrm{M}$ oxidizes into $\mathrm{M}^{\mathrm{n}+}$. At low overpotential, $\mathrm{M}^{\mathrm{n}+}$ ions dissolve in the CAM, close to the metal surface. If the anodic current density, i.e. the dissolution rate, is high enough, the local $\mathrm{M}^{\mathrm{n}+}$ concentration reaches the solubility limit, and an Al-containing spinel phase precipitates on the electrode surface. This spinel layer enables maintaining a low alumina activity underneath. If the polarization is maintained, a monoxide layer grows between the metal and the spinel layer. Depending on the $\mathrm{M}^{\mathrm{n}+}$ mobility in the monoxide layer, the latter is dense and adherent or contains pores and voids. Indeed, if the $\mathrm{M}^{\mathrm{n}+}$ mobility is low, the MO layer grows by inwards $\mathrm{O}^{2-}$ diffusion via grain boundaries: this leads to the formation of a dense and adherent layer. On the contrary, when the $\mathrm{M}^{\mathrm{n}+}$ mobility is high, the $\mathrm{M}^{\mathrm{n}+}$ ions diffuse rapidly from the MO layer towards the spinel phase and the electrolyte. This mass transfer creates pores and voids in the MO layer, in particular at the M/MO interface, which can finally lead to the loss of adhesion of the MO layer and the infiltration of electrolyte. Based on other studies [18,25,29] performed for longer duration and at higher current densities, it is believed that, in a later stage of the degradation, metal fluoride form between the oxide layer and the metal, due to oxide ion depletion in the infiltrated electrolyte.

\section{Acknowledgement}

This work was supported by Rio Tinto Alcan.

\section{References}

[1] I. Galasiu, R. Galasiu, J. Thonstad (Eds.), Inert Anodes for Aluminium Electrolysis, 1st ed., Aluminium-Verlag, 2007. p. 212.

[2] E.V. Antipov, A.G. Borzenko, V.M. Denisov, A.Y. Filatov, V.V. Ivanov, S.M. Kazakov, P.M. Mazin, V.M. Mazin, V.I. Shtanov, D.A. Simakov, G.A. Tsirlina, S.Y. 
Vassiliev, Y.A. Velikodny, Electrochemical behavior of metals and binary alloys in cryolite-alumina melts, Light Metals (2006) 403-408.

[3] Z. Shi, J. Xu, Z. Qiu, Z. Wang, B. Gao, Copper-nickel superalloys as inert alloy anodes for aluminum electrolysis, JOM 55 (11) (2003) 63-65.

[4] L. Cassayre, P. Chamelot, L. Arurault, L. Massot, P. Palau, P. Taxil, Electrochemical oxidation of binary copper-nickel alloys in cryolite melts, Corros. Sci. 49 (9) (2007) 3610-3625.

[5] D.A. Simakov, E.V. Antipov, M.I. Borzenko, S.Y. Vassiliev, Y.A. Velikodny, V.M Denisov, V.V. Ivanov, S.M. Kazakov, Nickel and nickel alloys electrochemistry in cryolite-alumina melts, Light Metals (2007) 489-493.

[6] S. Helle, B. Brodu, B. Davis, D. Guay, L. Roué, Influence of the iron content in CuNi based inert anodes on their corrosion resistance for aluminium electrolysis, Corros. Sci. 53 (10) (2011) 3248-3253.

[7] V. Chapman, B.J. Welch, M. Skyllas-Kazacos, Anodic behaviour of oxidised NiFe alloys in cryolite-alumina melts, Electrochim. Acta 56 (3) (2011) 1227 1238.

[8] V.A. Kovrov, A.P. Khramov, Y.P. Zaikov, V.N. Nekrasov, M.V. Ananyev, Studies on the oxidation rate of metallic inert anodes by measuring the oxygen evolved in low-temperature aluminium electrolysis, J. Appl. Electrochem. 41 (11) (2011) 1301-1309.

[9] G.C. Wood, T.G. Wright, The scaling of nickel and nickel-cobalt alloys in air, Corros. Sci. 5 (12) (1965) 841-857.

[10] D.P. Whittle, G.C. Wood, Two-phase scale formation on $\mathrm{Cu}-\mathrm{Ni}$ alloys, Corros Sci. 8 (5) (1968) 295-308.

[11] G.L. Wulf, T.J. Carter, G.R. Wallwork, The oxidation of FeNi alloys, Corros. Sci. 9 (9) (1969) 689-701.

[12] W.J. Tomlinson, M.J. Gardner, R.J. Kowalski, The scale constituents and spalling characteristics of Ni-Fe $(0-60 \%)$ alloys oxidized in air at $800-1200^{\circ} \mathrm{C}$, Corros. Sci. 17 (4) (1977) 301-304.

[13] R. Haugsrud, T. Norby, P. Kofstad, High-temperature oxidation of Cu-30 wt.\% Ni-15 wt.\% Fe, Corros. Sci. 43 (2) (2001) 283-299.

[14] R. Haugsrud, On the high-temperature oxidation of Fe Co., Ni and Cu-based alloys with addition of a less noble element, Mater. Sci. Eng., A 298 (1-2) (2001) 216-226.

[15] R. Haugsrud, High-temperature oxidation of Ni-20 wt.\% Cu from 700 to $1100^{\circ} \mathrm{C}$, Oxid. Met. 55 (5/6) (2001) 571-583.

[16] B.S. Kim, B.G. Kim, H.W. Lee, W.S. Chung, Kinetics of Fe-30\%Ni-12.5\%Co invar alloy during high temperature oxidation, Met. Mater. Int. 8 (4) (2002) $367-$ 373.
[17] V. Chapman, B.J. Welch, M. Skyllas-Kazacos, High temperature oxidation behaviour of Ni-Fe-Co anodes for aluminium electrolysis, Corros. Sci. 53 (9) (2011) 2815-2825.

[18] I. Gallino, M.E. Kassner, R. Busch, Oxidation and corrosion of highly alloyed Cu$\mathrm{Fe}-\mathrm{Ni}$ as inert anode material for aluminum electrowinning in as-cast and homogenized conditions, Corros. Sci. 63 (2012) 293-303.

[19] R.Y. Chen, W.Y.D. Yuen, Review of the high-temperature oxidation of iron and carbon steels in air or oxygen, Oxide Met. 59 (5-6) (2003).

[20] Q. Diep, F. Dewing, A. Sterten, The solubility of $\mathrm{Fe}_{2} \mathrm{O}_{3}$ in cryolite-alumina melts, Metall. Mater. Trans. B 33 (1) (2002) 140-142.

[21] T. Jentoftsen, E. Dewing, O.-A. Lorentsen, G. Haarberg, J. Thonstad, An electrochemical investigation of $\mathrm{Fe}(\mathrm{II})$ dissolved in a cryolite melt, Metall. Mater. Trans. B 43 (4) (2012) 869-874.

[22] T. Jentoftsen, O.-A. Lorentsen, E. Dewing, G. Haarberg, J. Thonstad, Solubility of some transition metal oxides in cryolite-alumina melts: Part I. Solubility of $\mathrm{FeO}, \mathrm{FeAl}_{2} \mathrm{O}_{4}, \mathrm{NiO}$, and $\mathrm{NiAl}_{2} \mathrm{O}_{4}$, Metall. Mater. Trans. B 33 (6) (2002) 901-908.

[23] P. Chamelot, B. Lafage, P. Taxil, Studies of niobium electrocrystallization phenomena in molten fluorides, J. Electrochem. Soc. 143 (5) (1996) 1570 1576.

[24] C.W. Bale, P. Chartrand, S.A. Decterov, G. Eriksson, K. Hack, R. Ben Mahfoud, J. Melançon, A.D. Pelton, S. Petersen, FactSage thermochemical software and databases, Calphad J. 62 (2002) 189-228.

[25] A.P. Khramov, V.A. Kovrov, Y.P. Zaikov, V.M. Chumarev, Anodic behaviour of the Cu82Al8Ni5Fe5 alloy in low-temperature aluminium electrolysis, Corros. Sci. 70 (2013) 194-202.

[26] A. Solheim, A. Sterten, Activity of alumina in the system $\mathrm{NaF}-\mathrm{AlF}_{3}-\mathrm{Al}_{2} \mathrm{O}_{3}$ at $\mathrm{NaF} / \mathrm{AlF}_{3}$ molar ratios ranging from 1.4 to 3, Light Metals (1999) $445-452$.

[27] N. Birks, G.H. Meier (Eds.), Introduction to high temperature oxidation of metals, Edward Arnold, Pittsburgh, 1983. p. 198.

[28] L. Cassayre, P. Chamelot, L. Arurault, P. Taxil, Anodic dissolution of metals in oxide-free cryolite melts, J. Appl. Electrochem. 35 (10) (2005) 999-1004.

[29] T.R. Beck, C.M. Macrae, N.C. Wilson, Metal anode performance in lowtemperature electrolytes for aluminum production, Metall. Mater. Trans. B 42 (4) (2011) 807-813. 